\title{
Water Quality Assessment of Begnas and Rupa Lakes, Lesser Himalaya Pokhara, Nepal
}

\author{
Ramesh R. Pant ${ }^{1}$, Khadka Bdr. Pal ${ }^{2 *}$, Nanda L. Adhikari ${ }^{3}$, Subash Adhikari ${ }^{4}$, Akkal D. Mishra ${ }^{3}$ \\ Central Department of Environmental Science, Tribhuvan University, Kathmandu, Nepal \\ ${ }^{2}$ Tri-Chandra Multiple Campus, Tribhuvan University, Kathmandu, Nepal \\ ${ }^{3}$ Prithvi Narayan Multiple Campus, Tribhuvan University, Pokhara, Nepal \\ ${ }^{4}$ Institute of Tibetan Plateau Research, Chinese Academy of Science, China \\ *Corresponding author: khadka.pal@gmail.com
}

Received: Nov 7, 2018

Revised: Jan 26, 2019

Accepted: Feb 4, 2019

\begin{abstract}
This study was conducted to assess water quality variations and identify potential pollution sources in two lakes namely Begnas and Rupa, Lesser Himalayas Pokhara, Nepal during monsoon season in June 2016. A total of 18 water samples ( $n=9$, from each lake) were collected and major physicochemical parameters were analyzed: $\mathrm{pH}$, electrical conductivity (EC), total dissolved solids (TDS), dissolved oxygen(DO), biological oxygen demand (BOD), nitrate-nitrogen $\left(\mathrm{NO}_{3}-\mathrm{N}\right)$, phosphate- phosphorus $\left(\mathrm{PO}_{4}-\mathrm{P}\right)$, ammonia, chloride, free $\mathrm{CO}_{2}$ and total hardness $(\mathrm{TH})$. The results revealed that the water of both lakes were relatively pure with very less TDS as compared to other lakes considered for the comparison with this study. However, the concentrations of $\mathrm{CO}_{2}$ and phosphates were found to be higher than WHO guidelines for drinking water and also indicated the problem of rapid eutrophication in both of the lakes. Thus, the higher concentrations of organic pollutants and the rapid eutrophication process could be the serious threats that should be considered by the concerned authorities for the sustainability of the lakes in future.
\end{abstract}

Keywords: Physico-chemical parameters, pollution, eutrophication, water quality, lesser himalaya

\section{Introduction}

Water is one of the most vital natural resources for the sustainability of human and other environmental components. Globally, surface water quality is governed by complex anthropogenic activities and natural processes including weathering, erosion, hydrological features, climate change, precipitation, industrial activities, agricultural land use, sewage discharge, and the human exploitation of water resources. The human impacts are becoming more intense on quantity and quality of lake waters, and are spreading in most parts of the world. Both the water sources i.e., lentic and lotic waters and other wetlands bodies play an important role in the processes that keep our environment healthy and productive. However it is inferred that the water quality in most countries has become a critical issue in recent years; exclusively because of concerns that freshwater will be a limited resource in the future. Good water quality in lake is essential for maintaining recreation and fisheries and for provision of drinking water to the people [21]. 
The lake ecosystems and other wetland areas are considered as one of the most productive ecosystems in the world. However, it is very unfortunate that these ecosystems are often viewed as wasteland, and more than $64 \%$ of the world's wetlands have disappeared since 1900's [13]. The waters from these environments are the source of drinking and domestic use for rural and urban population. Also, they have great role in the ecological processes that supports biodiversity, and maintain the ecological health of the environment. However, declining water quality due to environmental perturbations threatens the stability of biotic integrity and therefore, hinders the ecosystem services and functions of aquatic ecosystems. There are more than 5000 lakes in Nepal having an area of $>1$ ha and out of them, ten are listed in the list of Ramsar site [11]. The previous studies showed that the wetlands of Nepal are under threat by both natural and anthropogenic interferences and, hence the livelihoods of several wetland dependent communities are directly affected [4]. When sewage and agricultural run-off containing phosphates or other nutrients enter natural water bodies, they cause over nutrition, leading to eutrophication [7]. The high rate of deforestation and use of pesticides and fertilizers have spurred the spread of invasive species. Direct human influence is mostly absent in remote aquatic systems in the high Himalaya. However, anthropogenic activities are intense in midland and lowland and lead to eutrophication, pollution and degradation of water bodies particularly in urban and agricultural areas [21]. Most of the lakes of Nepal are located in the hilly region and almost all of them happen to be tectonic lakes. Among hill districts, the Kaski district possesses the largest number of lakes and all of them are confined to the Pokhara valley. Pokhara valley is situated around $200 \mathrm{~km}$ west of the Kathmandu, Nepal is one of the most popular tourism destinations, is also known as the "City of Lakes". Also Pokhara valley is one of the most popular tourism destinations of Nepal, is famous for heritages, caves, mountains, waterfalls and especially for the lakes namely: Phewa, Begnas, Rupa, Khaste, Dipang, Gude, Neurani, Maidi, Kamal Pokhari and the Seti River Basin. These lakes are declared as a $10^{\text {th }}$ Ramsar site from Nepal on $2^{\text {nd }}$ February 2016 [11]. This study was conducted to evaluate the ecological status of the two major lakes (Begnas and Rupa) of Pokhara valley, Nepal.

The Begnas and the Rupaare second and the third largest lakes, respectively from Pokhara, Nepal, are multipurpose lakes, used for domestic, irrigation, commercial fishing, recreational, hydropower generation, industrial and more importantly they have great contribution to the livelihoods of local people, ecological health and tourism as well. They are located just off the principal highway. The Begnas is the second largest lake (after Phewa-lake), lies at an altitude of $650 \mathrm{~m}$, with having surface area $3.28 \mathrm{~km}^{2}$ is a multipurpose freshwater lake used for irrigation, commercial fish production, recreation and other livelihood related activities. The water volume of the lake is $17.96 \times 10^{6} \mathrm{~m}^{3}[14]$. On the other hand, Rupa Lake (Fig. 1) is the third largest lake of Pokhara Valley situated in Kaski district of Nepal at an elevation of $600 \mathrm{~m}$. It is elongated north to south and the main inflow of water is from Talbeshi stream whereas Dhovan Khola is the feeder stream with its outlet, Talkhola at Sistani, joining the Seti-Gandaki. Rupa Lake is the third biggest lake of Pokhara valley. The total area of Rupa Lake is 115 ha and the total area of watershed is 30 square kilometer [11]. All the wetlands of Nepal are threatened by both natural and anthropogenic activities to some extent. Like many other regions in the world, the surface water is most vulnerable to pollution due to its easy accessibility for disposal of pollutants and waste waters in the Pokhara Valley also. The wetlands in Pokhara Valley are even more at the risk from drainage diversion, obstruction, siltation, encroachment, pollution, and several natural and anthropogenic activities. The people living around the major water sources in Nepal are directly connected with the wetland resources for their subsistence and economic wellbeing. The livelihoods of several communities' areas 
are based on wetland products and services. At least 20 ethnic and caste groups out of 103 are traditionally wetland dependent for their livelihoods in Nepal. The Begnas and the Rupa lakes are threatened by both natural and anthropogenic causes as the water quality has been deteriorating day by day due to its proximity to rapid urbanizing city, agglomeration and other unsustainable developmental activities, in addition to the usual ecological changes. In order to assess the water quality, this research has intensively examined the major physico-chemical parameters of the lakes.

\section{Materials and Methods}

\subsection{Study Area}

The Begnas and Rupa lakes cover total catchment area of about $18.4 \mathrm{~km}^{2}$ and $27.6 \mathrm{~km}^{2}$, respectively in western part of Nepal $\left(28^{\circ} 09^{\prime} 44^{\prime \prime}-28^{\circ} 13^{\prime} 04^{\prime \prime} \mathrm{N} 84^{\circ} 04^{\prime} 45^{\prime \prime}-84^{\circ} 07^{\prime} 35^{\prime \prime} \mathrm{E}\right.$ for Begnas and $28^{\circ} 07^{\prime} 52^{\prime \prime}-28^{\circ} 12^{\prime} 22^{\prime \prime} \mathrm{N} 84^{\circ} 05^{\prime} 43^{\prime \prime}-84^{\circ} 10^{\prime} 04^{\prime \prime} \mathrm{E}$ for Rupa).The Begnas lake is located at an altitude of about 637-1439 $\mathrm{m}$ above the sea level, whereas Rupa lake is at 590-1422 $\mathrm{m}$ above the sea level [11]. The study was carried out by collecting a total of 18 water samples ( 9 from each) from both the lakes water. The samples were taken during monsoon period June 2016 in sterilized bottles of a liter capacity. After the collection, the water samples were acidified immediately with adding $2 \mathrm{ml}$ concentrated nitric acid $\left(\mathrm{HNO}_{3}\right)$ as described by APHA, AWWA, and WPCT. The sampling bottles were labeled and delivered on the same day to laboratory. The samples were preserved at $4^{\circ} \mathrm{C}$ until further processing and analysis.

\subsection{Analysis of Physico-chemical Parameters}

In order to assess the water quality of the lakes, this research has intensively examined the major physico-chemical parameters at in-situ and laboratory. Before sampling for chemical test, proper cares was taken to make the container neat and clean to avoid the effects of impurities in the results [6]. The physiochemical parameters of the collected water samples were analyzed as per the standard methods. The water temperature, $\mathrm{pH}, \mathrm{EC}$ and TDS were detected using a multi-parameter water quality monitoring instrument (HANNA), dissolved oxygen (DO) was determined by modified Winkler method and free carbon dioxide $\left(\mathrm{CO}_{2}\right)$ was calculated by phenolphthalein indicator method on the onsite. Likewise, chloride was determined by using argentometric method, nitrate-nitrogen $\left(\mathrm{NO}_{3}-\mathrm{N}\right)$ by phenol disulphonic acid method and phosphate- phosphorus $\left(\mathrm{PO}_{4}-\mathrm{P}\right)$ by ammonium molybdate method. Similarly, biological oxygen demand (BOD) was measured in the laboratory by standards prescribed by APHA. Hardness was measured by the complexometric titration (EDTA) method and ammonia by colorimetric sodium nitropruside method after distillation of samples.

Table 1: Method of physico-chemical parameters analysis (Source: APHA, 2005)

\begin{tabular}{|c|c|}
\hline Parameters & Method used \\
\hline Temperature & Mercury- Thermometer \\
\hline $\mathrm{pH}$ & $\mathrm{pH}$ Meter \\
\hline Conductivity & Conductivity Meter \\
\hline Total Dissolved Solids & Multimeter Probe \\
\hline Chloride & Argentometric Method \\
\hline Total Hardness & EDTA Method \\
\hline Total Hardness & EDTA Method \\
\hline
\end{tabular}




\begin{tabular}{|c|c|}
\hline Dissolved Oxygen & Winkler's Method \\
\hline Biochemical Oxygen Demand & Five days BOD and Winkler's Method \\
\hline Free $\mathrm{CO}_{2}$ & Sodium Hydroxide Method \\
\hline Phosphate & Ammonium Molybdate Method \\
\hline Nitrate-N & Phenol Disulphonic Acid Method \\
\hline Ammonia & Sodium Nitropruside \\
\hline
\end{tabular}

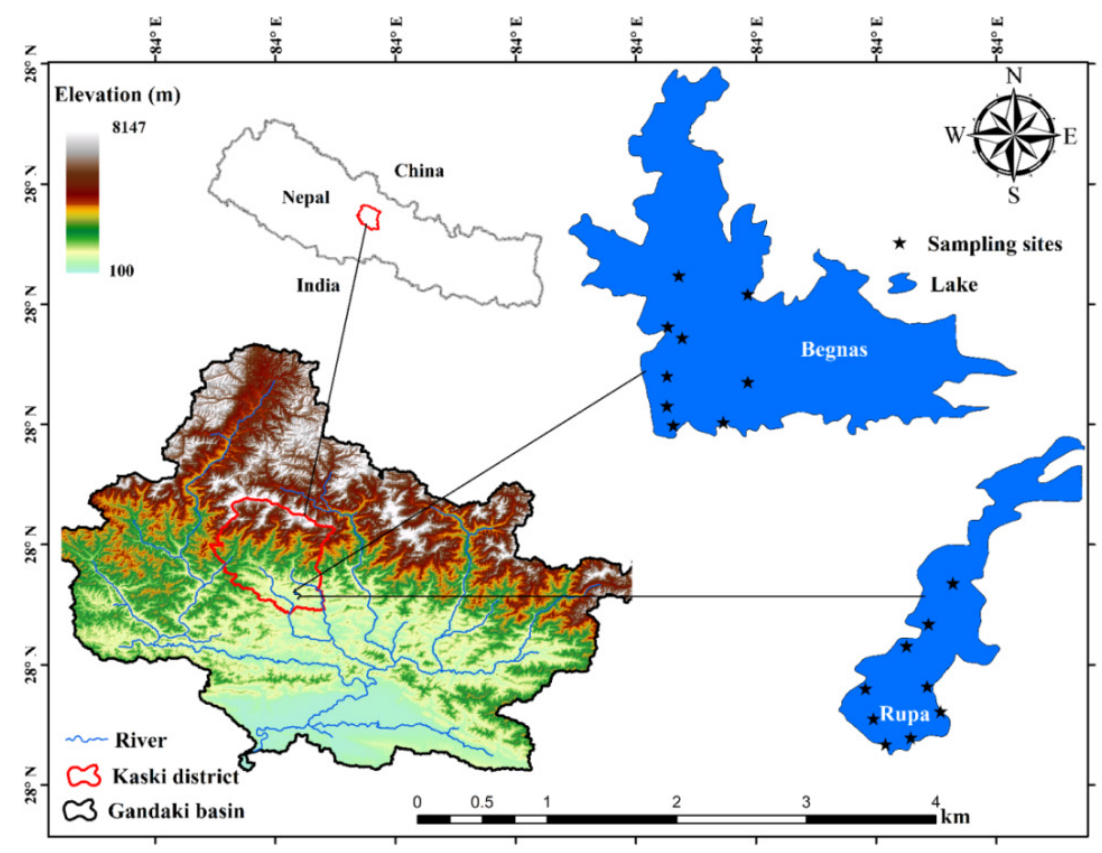

Fig. 1: Map showing sampling sites of the Begnas and Rupa lakes

\section{Results and Discussion}

The summary statistics of measured physicochemical parameters of the water in the Begnas and Rupa lakes of Pokhara are presented in Table 1. The results are then compared with WHO guideline value and other regional lakes from Nepal and India. The results revealed that the water temperature was recorded in the range of $23.50{ }^{\circ} \mathrm{C}$ to $26.60{ }^{\circ} \mathrm{C}$ in Rupa lake while $24.70^{\circ} \mathrm{C}$ to $28.00{ }^{\circ} \mathrm{C}$ in Begnas lake, which is relatively higher than Rupa lake during the study period. The temperature is one of the most important factors for aquatic environment as it regulates physicochemical and biological activities [15]. The increase in temperature may decreases the quality of water due to high interaction of various components and their high reactivity [22]. Also, the warmer water generally increases the rate of growth of plants and algae and their interactions with many aquatic animals. Thus, the warmer water obviously accelerates the decay of organic matter contents in the lake [3].

$\mathrm{pH}$ is one of the most important physic-chemical parameters that reflect the suitability of water for drinking and other purposes. The $\mathrm{pH}$ plays an important role on the biotic life both in lentic and lotic environments. The fluctuations in $\mathrm{pH}$ are mostly due to diurnal interplay of photosynthesis and respiratory processes of animal and plant communities. The results showed that the $\mathrm{pH}$ 
of the Rupa lake vary from $7.60-8.20$ but it was from 8.50-9.23 in the Begnas lake which is comparatively higher than the lake Rupa. The $\mathrm{pH}$ value of the Rupa lake in the present study was found within the guideline as recommended by WHO. The high $\mathrm{pH}$ indicates that carbon dioxide, carbonate and bicarbonate equilibrium is affected [5]. The $\mathrm{pH}$ values are usually changed by the presence of organic and inorganic solutes together with reaction of carbon dioxide [29]. However, the WHO guideline value (6.5-8.5) indicates that water of the Begnas lake exceeds the maximum limit indicating that high organic pollution and also could be due to the relatively high carbonate weathering in the lakes. The low $\mathrm{pH}$ indicates high acidity which can be caused by increased concentrations of $\mathrm{CO}_{2}$ and other acid forming substances in the waters [26].

Electrical conductivity (EC) is a measure of ionic strength i.e., the ability of an aqueous solution to carry an electric current. It depends on the presence of ions, on their total concentrations, mobility and temperature. Generally, higher value of the EC shows higher concentrations of dissolved ions i.e., high values of total dissolved solids (TDS). The EC values of sampling sites in both lakes were found in lower range as suggested by WHO standards due to low salinity and mineral contents. The moderate ionic strengths were reflected by $\mathrm{EC}$ in the waters of both the lakes. The presence of ions such as $\mathrm{Ca}^{2+}, \mathrm{Mg}^{2+}, \mathrm{Cl}^{-}, \mathrm{NO}_{3}{ }^{-}, \mathrm{PO}_{3}{ }^{3-}$ and $\mathrm{HCO}_{3}{ }^{-}$contribute to the salinity of water $[21,28]$. The excess TDS are natural or anthropogenic pollutants in the lake water and imparts the color, totality alkalinity and conducting nature of water. The TDS contents in the present study were found in the range of 33.00- $38.50 \mathrm{mg} \mathrm{L}^{-1}$ for Rupa lake which is comparatively higher than that of Begnas lake (i.e., $24.50-27.60 \mathrm{mg} \mathrm{L}^{-1}$ ). The higher value of TDS is generally harmful to both human and ecological health. For instance in case of human perspective, those who are the victims of kidney and heart disease, the high TDS containing water adversely affects them [1].

The total hardness in water is due to the sum of concentrations of alkaline earth metal ions such as $\mathrm{Ca}^{2+}, \mathrm{Mg}^{2+}[12]$. The total hardness is the total water soluble calcium and magnesium salt present water expressed as its $\mathrm{CaCO}_{3}$ equivalent. Total hardness includes bicarbonates, chlorides and sulphates of calcium and magnesium etc. In most of the natural water bodies, the bicarbonates of calcium ions are more with calcium than with magnesium and are even still less with sodium and potassium. It is reported that the consumption of excess salty water cause hypertension, the risk for stroke, renal stones and asthma [17]. The present study showed that the total hardness analyzed of the Rupa Lake found in the range of $13.80-18.50 \mathrm{mgL}^{-1}$ but in the Begnas lake it ranges from $12.80-147.00 \mathrm{mgL}^{-1}$. The values found in the Rupa lake are within the guideline of WHO. However its upper limit value for Begnas lake indicated that there is excessive hardness level rich in calcium and magnesium water soluble content than Rupa lake. The excess range of total hardness may cause rheumatism and urinary tract infection and are tough for persons with poor digestive system.

Chloride contents in water may be due to the minerals like mica, apatite and from the liquid inclusions through the igneous rocks, including some anthropogenic signature [10]. The main concentrations of chloride in lakes and pond were due to fecal deposition and household sewage. It is considered as the pollution indicator when present in high concentrations [7]. The chloride contents in the present study were found in the range of $12.78-21.30 \mathrm{mg} \mathrm{L}^{-1}$ for Rupa lake and $15.62-32.66 \mathrm{mg} \mathrm{L}^{-1}$ for Begnas lake. The values are well below the WHO guidelines for drinking water maximum permissible level $250.00 \mathrm{mg} \mathrm{L}^{-1}$ It is considered that chloride concentrations more than $200 \mathrm{mg} \mathrm{L}^{-1}$ is risky for human consumption and causes unpleasant taste of water [27]. The total ammonia contents in the drinking water sample was found to vary from $0.12-0.23 \mathrm{mgL}^{1}$ 
for Rupa Lake and $0.08-0.14 \mathrm{mg} \mathrm{L}^{-1}$ for Begnas lake. Most of the sampling sites recorded the total ammonia contents is within the normal guideline value of WHO. However the ammonia contents are comparatively less in Begnas lake. Excess concentration of ammonia is harmful to human health as well as aquatic animals. For instance, from the human health perspective, the high amount of ammonia may cause vomiting and gastric problems [25]. The high contents of ammonia may be due to natural degradation of most inevitably ammonification of organic matters and also due to the sewage contaminations [19].

The key nutrients for the growth of plants and algae are phosphorous and nitrogen, which are normally present in lake as $\mathrm{PO}_{4}^{3-}, \mathrm{NO}_{3}^{-}-\mathrm{NO}_{2}^{-}$and $\mathrm{NH}_{4}^{+}$etc. Due to these nutrients, the eutrophication is one of the major problems for the sustainability of the lake environments. The major sources of these chemicals in the lake water are from the raw or treated sewage, agriculture drainage and certain industrial wastes etc. The nutrients have also vital role in sustaining the aquatic life in the natural waters, e.g., the phosphorus behaves as growth limiting factor and is one of the basic nutrients for plants and microorganisms [7]. The concentrations of phosphates were found to be higher than WHO guidelines for drinking water and also indicated the problem of rapid eutrophication in both the lakes. The results of the present study are also with good agreement of previous studies carried out on the lake water quality as mentioned in the literature. Nitrate is an important nutritional factor in any water body that indicates the nature (oligo-trophic, meso-trophic, and eutrophic) and rate of eutrophication. There are many sources of $\mathrm{NO}_{3}-\mathrm{N}$ like sewage, domestic runoff, and runoff from the farmlands [7]. The concentrations of nitrate contents were found in the range of 2.10$2.80 \mathrm{mg} \mathrm{L}^{-1}$ for Rupa lake and 1.20-2.70 $\mathrm{mg} \mathrm{L}^{-1}$ for Begnas lake. The values are well below the WHO guidelines for drinking water maximum permissible level (i.e., $<75 \mathrm{mg} \mathrm{L}^{-1}$, Table 2). Besides several anthropogenic activities, atmospheric deposition and mineralization, and precipitation of $\mathrm{N}$-holding organic compounds may be other possible source of $\mathrm{NO}_{3}^{-}[14]$.

Table 2: Physicochemical characteristics of two Lesser Himalayan lakes (Rupa and Begnas), Pokhara, Nepal (All units in $\mathrm{mg} \mathrm{L}^{-1}$ (except EC: $\mu \mathrm{S} \mathrm{cm}^{-1}$, Temperature ${ }^{\circ} \mathrm{C}$ and $\mathrm{pH}$ ))

\begin{tabular}{|c|c|c|c|c|c|c|c|c|c|c|}
\hline \multicolumn{2}{|c|}{ Rupa Lake (n= 09) } & & & \multicolumn{3}{c|}{$\begin{array}{c}\text { Begnas Lake (n } \\
\text { =99) }\end{array}$} & & $\begin{array}{c}\text { WHO Value, } \\
\mathbf{2 0 1 6}\end{array}$ & Remarks \\
\hline Parameters & Min & Max & Mean & SD & Min & Max & Mean & SD & & \\
\hline Temperature & 23.5 & 26.6 & 25.45 & 0.94 & 24.7 & 28 & 26.73 & 0.94 & & \\
\hline EC & 46.3 & 54.2 & 52.33 & 1.98 & 32.5 & 39.3 & 35.76 & 1.57 & & \\
\hline TDS & 33 & 38.5 & 36.7 & 1.6 & 24.5 & 27.6 & 25.42 & 0.81 & & \\
\hline pH & 7.6 & 8.2 & 7.87 & 0.23 & 8.5 & 9.23 & 9.04 & 0.25 & $6.5-8.5$ & \\
\hline DO & 3.4 & 6.7 & 5.09 & 0.97 & 5.48 & 8.6 & 6.46 & 0.84 & 5 & \\
\hline BOD & 32.4 & 68.5 & 53.83 & 14.37 & 15.2 & 31.2 & 26.28 & 4.02 & $<75$ & \\
\hline Nitrate & 2.1 & 2.8 & 2.46 & 0.22 & 1.2 & 2.7 & 1.77 & 0.51 & 50 & \\
\hline Phosphate & 0.1 & 0.25 & 0.15 & 0.05 & 0.07 & 0.13 & 0.1 & 0.02 & 0.02 & High \\
\hline Ammonia & 0.12 & 0.23 & 0.17 & 0.03 & 0.08 & 0.14 & 0.1 & 0.02 & 1.5 & \\
\hline Chloride & 12.78 & 21.3 & 16.52 & 2.93 & 15.62 & 32.66 & 20.04 & 4.64 & 250 & \\
\hline Hardness & 13.8 & 18.5 & 16.53 & 1.62 & 12.8 & 14.7 & 13.75 & 38.2 & $<75$ & \\
\hline Free CO & 13.4 & 16.5 & 14.83 & 1.02 & 11 & 14.7 & 13.32 & 1.11 & $<10$ & High \\
\hline
\end{tabular}

Dissolved oxygen (DO) measures the amount of oxygen dissolved naturally in water. Generally, 
DO value should be greater than $4 \mathrm{mg} \mathrm{L}^{-1}$ and drinking purpose $6 \mathrm{mg} \mathrm{L}^{-1}$ for sustaining the healthy aquatic ecosystem and metabolic activities of microorganism [18]. The concentrations of DO varies from 3.40 to $6.70 \mathrm{mgL}^{-1}$ in Rupa lake and $5.48-8.60 \mathrm{mg} \mathrm{L}^{-1}$ in Begnas lake indicating that the mild organic pollution in the lakes. The DO value obtained showed that the lakes support the aquatic life. The high concentrations of organic pollution and the rapid eutrophication process are the serious threats that should be considered by the concern authorities for the sustainability of the lakes. The BOD is the measure of dissolved oxygen that is consumed by the microorganism i.e., degradable organic material present in water sample under the aerobic conditions [7]. The BOD contents in the present study were found in the range of 32.40- $68.50 \mathrm{mg} \mathrm{L}^{-1}$ in Rupa Lake and 15.20-31.20 $\mathrm{mg} \mathrm{L}^{-1}$ in Begnas Lake. The values are well below the WHO guidelines for drinking water maximum permissible level $<75 \mathrm{mg} \mathrm{L}^{-1}$ (Table 2).

The concentrations of free $\mathrm{CO}_{2}$ has vital role in proton producing mechanisms in the hydro-chemical processing in the lakes. In present study, the higher free $\mathrm{CO}_{2}$ contents indicate the dominancy of atmospheric $\mathrm{CO}_{2}$ dissolution and dissociation, which is the dominant producer of protons used for weathering in both the lakes [21]. Moreover, the study revealed that the relative concentrations of $\mathrm{CO}_{2}$ are found more in Rupa than that of the Begnas Lake, which could be the results of complex natural and anthropogenic activities such as process of bicarbonate formation due to underlying lithlogy, and burning of biomass nearby settlements [21].

Table 3: Comparisons of physicochemical parameters of lakes Rupa and Begnas with other lakes (All units in $\mathrm{mg} \mathrm{L}^{-1}$ (except EC: $\mu \mathrm{S} \mathrm{cm}^{-1}$, and $\mathrm{pH}$ ), ${ }^{*} \mathrm{TDS}$ calculated from EC)

\begin{tabular}{|c|c|c|c|c|c|c|c|c|c|c|c|c|}
\hline Lakes & $\mathbf{p H}$ & $\mathbf{E C}$ & $\mathbf{T D S}$ & $\mathbf{C l}^{-}$ & $\mathbf{N O}_{3}^{-}$ & $\mathbf{P O}_{4}^{-3}$ & $\mathbf{N H}_{3}-\mathbf{N}$ & Hardness & $\mathbf{D O}$ & $\mathbf{B O D}$ & $\mathbf{C O}_{2}$ & Reference \\
\hline Begnas & 9.04 & 35.76 & 25.42 & 20.04 & 1.77 & 0.10 & 0.10 & 13.75 & 6.46 & 26.28 & 13.32 & Present study \\
\hline Rupa & 7.87 & 52.33 & 36.70 & 16.52 & 2.46 & 0.15 & 0.17 & 16.53 & 5.09 & 53.83 & 14.83 & Present study \\
\hline Begnas & 7.3 & 90.5 & $48.87^{*}$ & 2.6 & 5.3 & - & - & - & - & - & - & $\begin{array}{c}\text { Khadka \& } \\
\text { Ramanathan } \\
2013\end{array}$ \\
\hline Nagdaha & 7.8 & 195.1 & 106 & 27.07 & 1.64 & 0.21 & - & 67.69 & 7.09 & 11.4 & 31.7 & Pant, 2013 \\
\hline Nainital & 8.7 & 706 & $381.24^{*}$ & 15.3 & - & - & & - & - & - & - & $\begin{array}{c}\text { Das, et al., } \\
2005\end{array}$ \\
\hline Khaste & 6.28 & - & - & 42.34 & 0.002 & 0.003 & - & 41.91 & 6.41 & & 8.41 & $\begin{array}{c}\text { Shrestha, } \\
2012\end{array}$ \\
\hline Chadra & 8.1 & 212 & $114.48^{*}$ & 0.5 & 0.5 & - & - & - & - & - & - & $\begin{array}{c}\text { Singh et al., } \\
2016\end{array}$ \\
\hline Pandoh & 7.1 & 80.8 & $43.63^{*}$ & 2.4 & 10.3 & - & - & - & - & - & - & $\begin{array}{c}\text { Ramshumali \& } \\
2007\end{array}$ \\
\hline Renuka & 8.4 & 590 & $318.6^{*}$ & 11.9 & - & - & - & - & - & - & - & $\begin{array}{c}\text { Das \& Kaur, } \\
2001\end{array}$ \\
\hline
\end{tabular}

The comparative assessment of the physicochemical parameters of water from the selected lakes is shown in table. The observed data indicates that the nature of water in all lakes is alkaline except the Khaste. It was found that the EC values of the most lakes are more or less comparable; however, the values are relatively higher in the Renuka and Nainital, which may be probably due to chemical analysis carried out during pre-monsoon season or due to excess salinity and mineral contents. 
The present status for chloride contents of Begnas lake is almost two times higher as compared to the results obtained during the period of 2013. Due to household discharges and presence of organic waste from animal origin, the organic wastes could be elevated in the lakes. Begnas Lake is nearly three times less than three years ago indicates lesser use of agriculture fertilizer. The nitrate level in Begnas and Rupa lakes are comparatively higher than other lakes indicates the excessive use of agriculture fertilizers, decayed vegetables, domestic effluents, leachate from refuse dumps, atmospheric precipitation etc. which could be the serious problem in future.

Similarly, the chloride contents in most of the lakes were comparable except Chandra and Pandoh. It is found that the TDS values of Begnas and Rupa lakes was relatively lower than other lakes indicating less extent of natural and anthropogenic inputs in two lakes. The DO value of different lakes for which data are provided indicates that the values are comparable to each other, indicating mild organic pollution. The BOD value indicates that the condition of Begnas and Rupa lakes is better than Nagdaha. The relatively low values of DO in Nagdaha are indicative of polluted nature of water body to some extent. This study provides the detailed information on water quality of the Begnas and Rupa lakes in comparison with other lakes. Also, the water quality in both the lakes is found to be determined by natural and anthropogenic inputs in both lakes. The status of ionic strength of Begnas and Rupa lakes is relatively low than other lakes, however due to anthropogenic inputs like more organic pollution and the rapid eutrophication process could be the serious threats and needs restoration of the lakes.

\section{Conclusion}

The study of physiochemical parameters is carried out in Begnas and Rupa lakes of Pokhara, Nepal. Considering the importance of water quality in the lentic environments, the study focuses on the assessment of physicochemical parameters of the waters in Pokhara and is compared to each other, regional levels and the WHO guideline values. The results revealed that the water quality of lesser Himalaya lakes of Pokhara, Nepal in monsoon season has mostly retained their natural quality, or both lakes are much less polluted, however, some of the parameters e.g., $\mathrm{pH}, \mathrm{CO}_{2}$ and phosphate exceeded their WHO guideline values to some extent. The $\mathrm{pH}$ values are usually altered by the presence of organic and inorganic solutes together with reaction of carbon dioxide. These indicate high concentrations of organic pollution and the rapid eutrophication process could be the serious threats that should be considered by the concern organizations for the sustainability of the lakes. However, on the basis of physiochemical parameters, lakes were found in ecologically acceptable condition; water was also suitable for aquaculture and irrigation. In addition, it is found that water quality of lake could be threatened by deforestation, sedimentation, eutrophication and encroachment of land around the lake area. The study has identified that the both of the lakes play crucial role for the local livelihoods and ecological sustainability in the region. Thus, it is essential and important to assess the lake water quality before it is used for drinking, domestics, agricultural, industrial purposes, recreation and fisheries etc. Moreover, the rapid urbanization and discharge of domestic sewage, solid waste dump and industrial effluent to the lake would be the other major threats for the sustainability of the lake. Once the lake water is contaminated, its dilution process is relatively slow comparing to the lotic environments and quality cannot be restored on time. It is therefore regular monitoring of lentic environment become imperative to maintain their quality. The knowledge obtained from this study could be a reference for the sustainable management of water quality in the Himalaya lakes. 
Acknowledgement: The authors are thankful to the Central Department of Environment Sciences, Kirtipur for providing laboratory facilities to carry out the analytical work and Mr. Ramesh Basnet for supporting in the laboratory work.

\section{References}

[1] Al-hadithi M (2012), Application of water quality index to access suitability of ground water quality for drinking purposes in Ratmao-Pathri Rao watershed, Haridwar District, India, American Journal of Scientific and Industrial Research, 3(6):396-402.

[2] Anshumali, Ramanathan AL (2007), Seasonal variation in the major ion chemistry of Pandoh Lake, Mandi District, Himachal Pradesh, India, Appl Geochem, 22:1736-1747.

[3] Asthana DK and Asthana M (2003), Environment- problems and solutions, S Chand and Company Ltd., New Delhi,India.

[4] Bhuju DR, Sharma S, Jha PK and Gaire NP (2012), Scientific Discourse of Lakes in Nepal, Nepal journal of Science and Technology, 13: 147-158.

[5] Chaurasia S, Tripathi P and Sharma TD (2017), Water quality evaluation of River Gomti at Lucknow, India, Journal of Environmental Science, Computer Science, Engineering and Technology, 6(4): 428-438.

[6] Ciaccio LL (1971), Water and Water pollution Handbook, Marcel Dekker Inc. New York, 2: 452-460.

[7] De AK (2000), Environmental Chemistry. New Age International (P) Ltd., New Delhi, 4: 201.

[8] Das BK (2005), Environmental pollution impact on water and sediments of Kumaun lakes, Lesser Himalaya, India: a comparative study. Environ Geol, 49:230-239.

[9] Das BK, Kaur P (2001), Major ion chemistry of Renuka Lake and weathering processes, Simaur District, Himachal Pradesh, India. Environ Geol, 40:908-917.

[10] Das PK, Malik SD (1988), Groundwater of Khatra region of Bankura district, West Bengal. Some chemical aspects in reference to its utilization. J Indian Water Resour Soc, 8(3):31-41.

[11] DNPWC (2016), Lake Cluster of Pokhara Valley: Department of National Parks and Wildlife Conservation and International Union for Conservation of Nature and Natural Resources.

[12] Fulvio DE and Olori L (1965), In: Hardness of drinking water and Public health, Pergamon Pub. NY.

[13] https://www.ramsar.org/activity/world-wetlands-day-2015.

[14] Khadka UR and Ramanathan (2013), A Major ion composition and seasonal variation in the Lesser Himalayan Lake: case of Begnas Lake, Pokhara, Nepal, Arabian Journal of Geosciences, 6:4191-4206.

[15] Kumar A, Gupta HP and Singh DK (1996), Impact of sewage pollution on chemistry and primary productivity of two fresh water bodies in Santal Paragana (Bihar), India. J. Ecol., 23: 82-86.

[16] Mandal B and Roy US (2008), Extraction chromatographic method of preconcentration and separation of lead (II) with high molecular mass liquid cation exchanger, 10, Indian J. Chem. A, 47:1497-1502.

[17] McCarthy MF (2004), Should we restrict chloride rather than sodium? Medical hypotheses, 63: 138-148.

[18] Onozeyi DB (2013), Assessment of some physico-chemical parameters of River Ogun (Abeokuta, Ogun state, southwestern Nigeria) in comparison with national and international standards, International Journal of Aquaculture, 3(15): 79-84.

[19] Pandey VP, Chapagain SK and Kazama F (2010), Evaluation of ground water environment of 
Kathmandu Valley. Environ. Earth Scie., 60: 1329-1342.

[20] Pant RR (2013), Water Quality Assessment of Nagdaha Lake, Lalitpur, Nepal, Perspectives on Higher Education, TUTA, Journal of University Campus Unit, Kirtipur, 8: 52-56.

[21] Pant RR, Zhang F, Rehman FU, Wang G, Ye M, Zeng C and Tang H (2018), Spatiotemporal Variation of hydrogeochemistry and its controlling factors in the Gandaki River Basin, Central Himalaya Nepal, Science of the Total Environment, 622-623:770-782.

[22] Parihar SS, Kumar A, Gupta RN, Pathak, M, Shrivastav, A and Pandey AC (2012), PhysicoChemical and Microbiological Analysis of Underground Water in and Around Gwalior City, MP, India, Research Journal of Recent Sciences, 1(6): 62-65.

[23] Shrestha G (2012), Water Quality Assessment of Khaste Lake, Pokhara, Nepal, Prithvi, a Multidisciplinary Research Journal, 5:1-5.

[24] Singh VB, Ramanathan AL and Mandal A (2016), Hydrogeochemistry of high-altitude Lake: a case study of the Chandra Tal, Western Himalaya, India, Arabian Journal of Geosciences, DOI:10.1007/s12517-016-2358-1.

[25] Trivedi RK and Goel PK (1986), Chemical and biological methods for water pollution studies, Environmental Publications, Oriental Printing Press, Aligarh.

[26] US EPA (2006), Global Environment Monitoring System/Water Program, Water quality for ecosystem and human health.

[27] Versari A, Parpinello GP and Gallasi S (2002), Chemometric survey of Italian bottled mineral waters by means of their labeled physico-chemical \& chemical composition, J. Food Compos and Anal, 15:251-264.

[28] Wetzel RG and Likens GE (1991), Limnology Analyses, Springer - Verlag, New York.

[29] Wetzel RG (1975). Limnology, W. B. Saunders co., Philadelphia, USA, 743. 